\title{
THE FIRST RECORD OF GAVIALOSUCHUS AMERICANUS SELLARDS (1915) † (EUSUCHIA: CROCODYLIDAE, TOMISTOMINAE) FOR THE LATE TERTIARY OF COSTA RICA AND CENTRAL AMERICA
}

\author{
César A. Laurito ${ }^{1,2^{*}} \&$ Ana L. Valerio ${ }^{3}$ \\ ${ }^{1}$ INA, Instituto Nacional de Aprendizaje, CENETUR \\ ${ }^{2}$ Investigador Asociado, Departamento de Historia Natural, Museo Nacional de \\ Costa Rica; Apdo. 203-2200, Coronado, San José, Costa Rica. \\ ${ }^{3}$ Departamento de Historia Natural, Museo Nacional de Costa Rica; Apdo. \\ 749-1000, San José, Costa Rica. \\ *Autor para contacto: cesarlaurito@ice.co.cr
}

(Recibido 20/05/07; aceptado: 12/12/08)

\begin{abstract}
Fossil remains of false gharials or Tomistominae crocodiles, were recovered from fluvial sediments associated with Late Miocene-Early Pliocene sub-aquatic fan deltaic deposits of the Curré Formation, in southern Costa Rica. The record of long-snouted crocodiles from southern Central America allows for a better knowledge of the evolution and composition of the paleoherpetofauna and its paleobiogeographical relationships with North American paleofaunas.

Key words: Reptilia, Crocodylidae, Tomistominae, Gavialosuchus, Tertiary, Costa Rica.

RESUMEN: Se recuperaron restos fósiles de falsos gaviales o cocodrilos Tomistomos en sedimentos fluviales asociados con antiguos abanicos deltaicos subacuáticos de la Formación Curré, de edad Mioceno Superior-Plioceno Inferior del sur de Costa Rica. El registro de cocodrilos longirrostros en el sur de América Central, permite una mejor comprensión de la composición y evolución de su paleoherpetofauna y su relación paleobiogeográfica con las paleofaunas norteamericanas.

Palabras clave: Reptilia, Crocodylidae, Tomistominae, Gavialosuchus, Terciario, Costa Rica.
\end{abstract}




\section{INTRODUCTION}

The gharials are a group of long-snouted crocodiles. They are represented today in the Indian subcontinent by only one species, Gavialis gangeticus. The available fossil evidence indicates that gharials arrived in South America during the Middle Eocene or perhaps before (Buffetaut, 1982; Langston \& Gasparini, 1997). In South America, the fossil record of species associated with this family is particularly abundant, mainly from the Miocene, found in Colombia, Venezuela and Brazil. They have also been found in Africa. One of the oldest fossil records of a gavial for tropical America comes from the Upper Oligocene in Puerto Rico (Vélez-Juarbe et al., 2006).

Brochu (2006) considers that the true gharials reached North America in the Maastrichtian and may have become extinct in the Eocene. Later, during the Late Oligocene, the "false gharials" are thought to have arrived. One possibility is that at this time the "false gharials" took over the habitat of the true gharials and replaced them. The "false gharials", are represented by the living species Tomistoma schlegelii that lives in Thailand, Malaysia and Indonesia. Fossils of T. schlegelii have also been found in China (Young, 1964). In addition, Antunes (1961) described fossils associated with the Tomistoma genus dating from the Miocene in Europe.

North America has an interesting fossil record of the "false gharials" or tomistomine crocodiles, represented by the genus Gavialosuchus, which is related to the Old World genus Tomistoma (sensu Brochu, 2001). According to Sill (1968), the Tomistominae crocodiles probably became differentiated from the main crocodilian line in Eurasia during the Late Cretaceous and likely reached their apogee in the Early Miocene, when they became common in fresh water and estuarine deposits of Africa and Europe. It is assumed that the Gavialosuchus genus originated from the European tomistomines that probably entered North America during the Early Eocene (Estes \& Báez, 1985). However, no fossil evidence of this type older than Late Oligocene has been found to this day (Brochu, 2006).
Central America, unlike South and North America, has a poorly developed fossil record of reptiles (see Mook, 1959). The fossil remains thus far found have been limited to a few osteoderms, vertebrae and isolate teeth without taxonomic value. Therefore we know that the crocodiles are as yet a particularly undiscovered and unknown group.

The present paper intends the first detailed description of the fossil record of the Gavialosuchus species for Central America.

The fossils were recovered from the locality of Limoncito, located at the coordinates $88^{\circ} 51^{\prime}$ 23.3" $\mathrm{N}$ and $83^{\circ} 04^{\prime} 19.7^{\prime}$ ' W, $16 \mathrm{~km}$ westward of the town of San Vito, nearby of the town of San Gerardo (Fig. 1). They are housed in the Section of Geology of the Department of Natural History of the National Museum of Costa Rica.

\section{GEOLOGY}

The fossils recovered come from a conglomeratic level $50 \mathrm{~cm}$-thick that unconformably overlies a $2.0 \mathrm{~m}$-thick-bank of glauconitic blue clay, arranged in centimeter to decimeter layers, with occasional carbonaceous laminated levels.

The conglomerate is composed of approximately 5\% subangular to angular clasts of basalt and andesite and around 95\% well rounded ripup clasts of blue glauconitic clay, with variable diameters between 2 and $8 \mathrm{~cm}$. Most of the clasts are matrix supported, floating in a matrix constituted by blue clay and fine sand. The conglomerate bank is made up of several sedimentary channels superimposed atop each other. Each one is represented by a new layer of clasts, with an internal fining upward structure. The blue clays correspond to the sedimentary marine facies from the outer continental shelf of the Curré Formation. The conglomerate is overlain by a $5 \mathrm{~m}$-thick bank of middle to coarse grained sandstones with occasional centimeter- to decimeter-amplitude lenses of mudstones, siltstones and pebbles.

The geometry of the conglomerate facies corresponds to a fan delta, associated with subaqueous fluvial sediments deposited in the mouth 

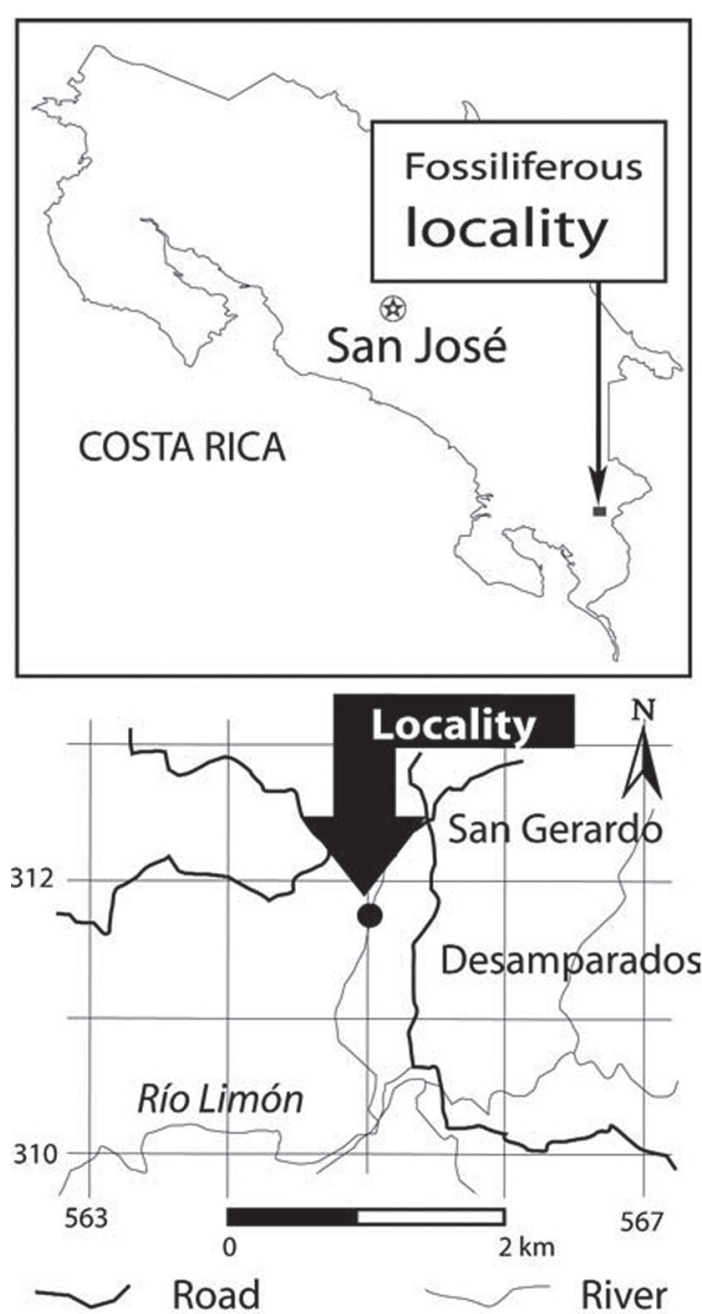

Fig. 1: Map of the locality of Limoncito, Coto Brus county, Puntarenas, Costa Rica. Coordinates according to Costa Rica Lambert Norte, used by the Instituto Geográfico Nacional, Coto Brus quadrangle.

of an old river system. These conglomerates are sometimes interlocked in and overlain by coastal sandy facies. Therefore, they clearly comprise the top of the Curré Formation. As such, they should not be confused with the fluvial conglomerates of the Paso Real Formation.

In the Curre Formation it is common to find carbonized wood and blue clay rip up clasts in the conglomerates perforated by Pholadidae mollusks, characteristic of the Gastrochaenolites ichnofossil type. Parautochtonous colonies of cirripedia and oyster remains were also recovered. All these elements confirm the existence of infra-coast hard grounds, characteristic of the Trypanites ichnofacies (sensu Freyt \& Seilacher, 1980).

\section{PALAEONTOLOGY}

The systematic taxonomy applied in this work is partly based on Brochu (1997, 1999, 2001 and 2006).

Legion ARCHOSAUROMORPHA Huene, 1946 Cohort CROCODYLOTARSI Bento \& Clark, 1988 Magnorder SUCHIA Krebs, 1974 Grandorder CROCODILIFORMES Hay, 1930 Order EUSUCHIA emended Huxley, 1875 Family CROCODYLIDAE Cuvier, 1807 Subfamily TOMISTOMINAE Eastman, 1902 (sensu Kälin, 1955)

Genus Gavialosuchus Toula \& Kail, $1885 \dagger$ Gavialosuchus americanus (Sellards, 1915) $\dagger$

$\dagger$ Thecachampsa sericodon Cope, 1869 sensu Cope 1869, p. 91.

$\dagger$ Thecachampsa sericodon Cope, 1869 sensu Cope 1875, p. 363.

$\dagger$ Tomistoma americana Sellards, 1915; pgs.135138 , figs. $1-2$.

$\dagger$ Tomistoma americana Sellards, 1915; sensu Sellards, 1916, pgs. 237-240, figs. 2-3.

$\dagger$ Gavialosuchus americana (Sellards, 1915) sensu Mook, 1921, pgs. 33-41, pls. 5-9.

$\dagger$ Gavialosuchus americana (Sellards, 1915) sensu Mook, 1924, pgs. 1-2, fig. 1.

$\uparrow$ Crocodilus sericodon (Cope, 1867) sensu Rapp, 1944; p. 287, list.

$\dagger$ Gavialosuchus americanus (Sellards, 1915) sensu Auffenberg, 1954, pgs. 185-209, figs. 2-3.

$\dagger$ Gavialosuchus americanus (Sellards, 1915) sensu Morgan; 1986, pgs. 412-415, fig. 1.

$\dagger$ Gavialosuchus americanus (Sellards, 1915) sensu Meylan et al. 2001; pgs. 139-141, figs. 7.3-7.5. $\dagger$ Thecachampsa antiqua (Leidy, 1852) sensu Myrick, 2001, pgs. 219-225, figs. 1-5. 


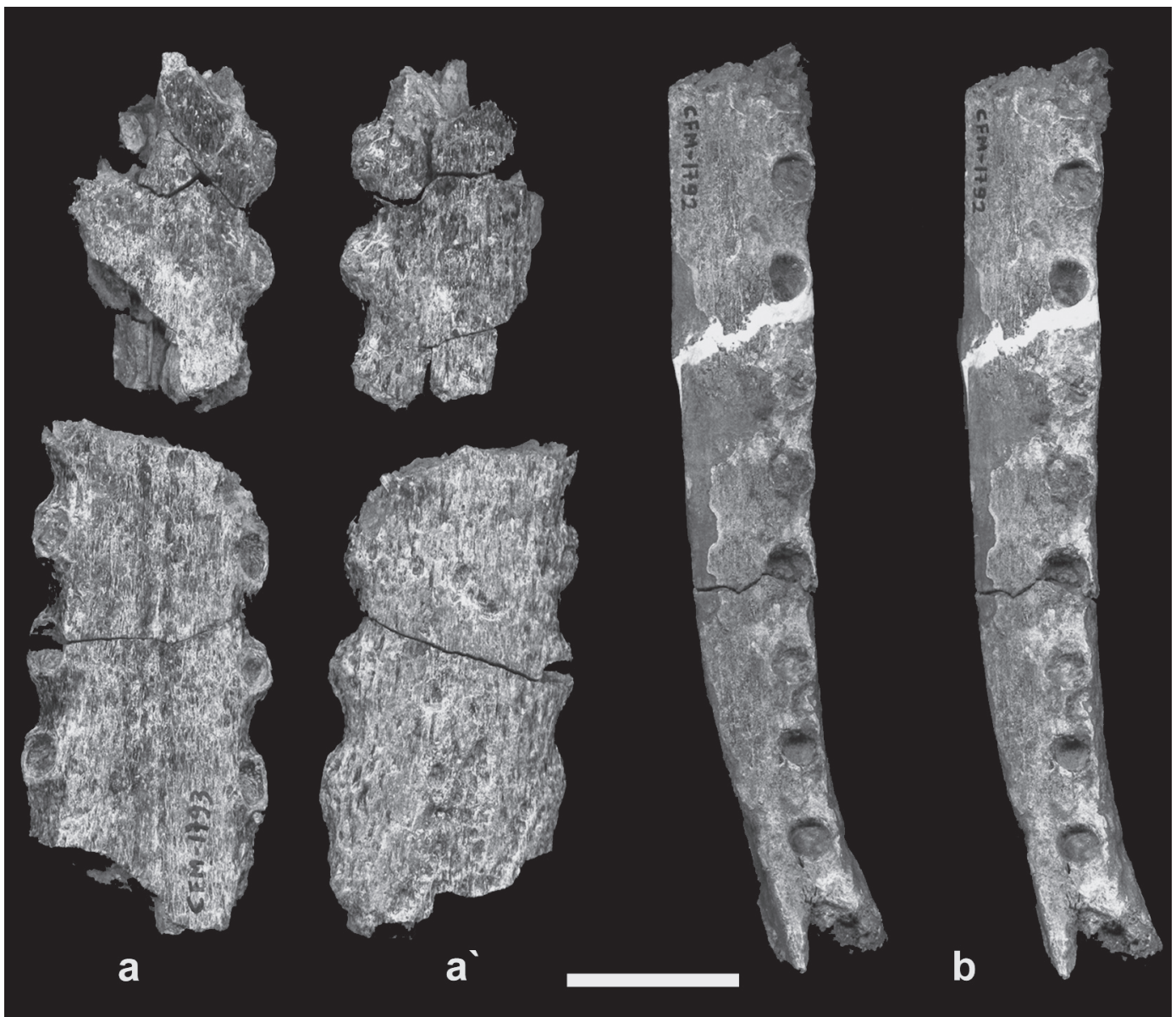

Fig. 2: Sample CFM-1793: Two fragments of the same jaw in a) oral view and a') external view; and b) a stereographic par of CFM-1792: a right fragment of the dentary. Visual scale bar: $30.0 \mathrm{~mm}$.

Synonymy: In this work we do not accept the synonymy of the species Thecachampsa antiqua (Leidy, 1852) for the species Gavialosuchus americanus (Sellards) proposed by Myrick (2001), since the criteria given by Meylan et al. (2006), are followed to clarify the species $T$. antiqua (Leidy, 1852) is based only on an isolated tooth of questionable taxonomic value.

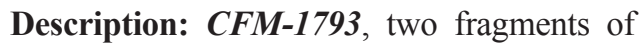
the same jaw. In the anterior portion, the second, third and partial fourth right alveoli are observed. In the posterior portion, the fifth, sixth, and seventh right and left alveoli are preserved. The eighth right alveolus is also partially preserved (fig. 2a-a').

The jaw is thin. In the proximity of the seventh alveolus, the width is $39.48 \mathrm{~mm}$ and $37.75 \mathrm{~mm}$ in the fifth alveolus.
The ventral face of the jaw is convex and rough, and the oral surface is flat and shows a symphyseal suture along its extension, the alveoli are well separated and parallel on both sides of the jaw, but slightly asymmetric.

The disposition of the alveoli suggests the teeth project slightly forward and strongly upwards. The diameters of the second, third, fifth, sixth and seventh right alveoli are 6.80, 7.21, 7.80, 7.95 and $7.34 \mathrm{~mm}$, respectively. Diameters of fifth, sixth and seventh left alveoli are 7.73, 7.56 and 8.02 $\mathrm{mm}$, respectively.

CFM-1792: A right fragment of the dentition with a rough vestibular surface and smooth lingual surface is shown with eight alveoli and a fragmented tooth. The diameter of the alveoli varies from 6.32 to $7.10 \mathrm{~mm}$ (fig. $2 \mathrm{~b}$ ). 

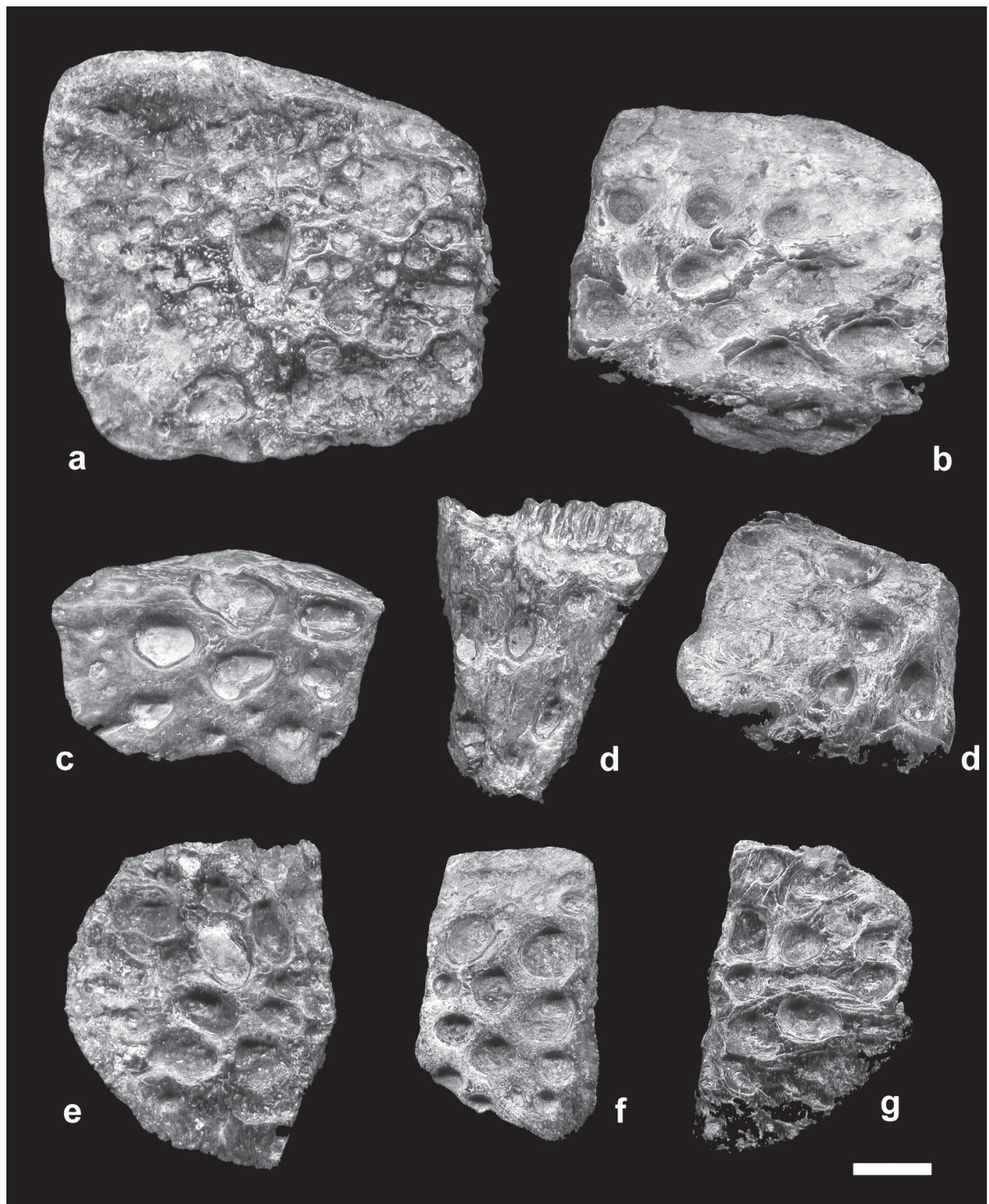

Figure 3: Osteoderms of uncertain position of Gavialosuchus americanus (Sellards, 1915), without dorsal ridge. a) CFM-960; b) CFM-1923; c) CFM-1916; d) CFM-1538; e) CFM-; f) CFM-1774; g) CFM-972 and h) CFM-1913. Visual scale bar: $10 \mathrm{~mm}$.

Osteoderms: CFM-960, 972, 1774, 1912, 1913, 1916 and 1923 among others, display particular characteristics found in Gavialosuchus like: absence of the spine or dorsal ridge and the presence of holes distributed more or less in a radial way in the osteoderms with an oval pattern and random way in a rectangular osteoderm (figs. 3a-h).

Discussion: The remains of jaws recovered, came from two different individuals of Tomistominae crocodile. The CFM-1793 corresponds to the symphyseal 
portion of the jaw and the CFM-1792 to the right hemi mandible. This symphyseal fragment is typical of a thin and long snouted crocodile. However, the reduced number and disposition of the alveoli, along with the relatively reduced dimensions of the dentitions, discard the possibility of a Gavialidae and confirm a Tomistominae crocodile, particularly a Gavialosuchus species. The morphology of some of the recovered osteoderms also confirms the presence of Gavialosuchus genus. The bony elements recovered, suggest these fossil specimens represent youthful individuals of Gavialosuchus americanus (Sellards, 1915).

Paleobiogeographic distribution: Gavialosuchus americanus (Sellards, 1915) has been described for the late Early Miocene to early Middle Miocene of the Kirkwood Fm., New Jersey (Cope, 1869, 1875; Rapp, 1944), the Calvert Fm., Maryland and Chesapeake Group, Virginia (Clark et al., 1904), the Pungo River and Yorktown Fms. in Lee Creek Mine, North Carolina (Myrick, 2001); the Middle to Late Miocene and Lower Pliocene of Florida (Sellards, 1915, 1916; Mook, 1921, 1924; Auffenberg, 1954; Meylan et al. 2001); the Middle Miocene of California and the Early Pliocene of Baja California (Myrick, 2001).

On the other hand, in South America, SánchezVillagra et al. (2000) tentatively classified an osteoderm recovered from the Lower Miocene of the El Castillo Formation in Venezuela, to the Gavialosuchus americanus species. However, Brochu \& Rincón (2004) analyzed this material as well as newly recovered remains from the El Castillo formation and concluded that this is a new genus and species of Gavialoidea.

Paleoecology: Auffenberg (1954) suggested that the species $G$. americanus also lived in shallow waters next to the coast and in estuaries. Meylan et al. (2001) indicated that it lived in the mouth of old rivers. This hypothesis corresponds with the sedimentological evidence found associated with these fossil remains. In addition, the remains of Gavialosuchus were similar to other reptiles like the Tryonichidae genus: Apalone (Laurito et al., 2005). Numerous remains of turtles and a Crocodylidae species (erroneously assumed to be of Pleistocene age by Mead et al., 2004 and 2006) demonstrate the existence of an ancient wetland environment.
Age: The foraminifera assemblage obtained from the blue clays of the Curré Formation, suggest that the age of this clay correspond to Upper Miocene, since other varieties of species from the Pliocene or Middle Miocene were not found. The identified species which have a wide stratigraphic range are: Globigerinoides quadrilobatus trilobus and Orbulina universa (D. Pizarro, written com., 2006). This provides conclusive evidence that the oldest age facies of the conglomerates would have to be an Upper Miocene age. It is also true that the conglomerate is overlain by an unconformity of blue clay beds, and therefore it is probable that the age of this outcrop is slightly younger; perhaps as much as the Lower Pliocene. On the other hand, the stratigraphic range of the species Gavialosuchus americanus (Sellards), varies from early Middle Miocene to Lower Pliocene or Barstovian (12-13 Ma) to Hemphillian (4.5 to $7 \mathrm{Ma}$ ) according to Morgan (1986). Therefore a NALMA (North American Land Mammals Age) age of late Hemphillian is assumed likely for to the present finding.

\section{CONCLUSION}

For the first time in Central America, the genus Gavialosuchus and the species G. americanus (Sellards, 1915) are being described. These Costa Rican finds represents the southernmost distribution of this species on the American continent.

The sedimentary environment in which the remains of Gavialosuchus were recovered is associated with conglomeratic lithology that corresponds to facies of subaquatic fan deltas. These facies confirm that the species Gavialosuchus americanus (Sellards, 1915) indeed inhabited brackish waters and probably entered the sea to transfer from the mouth of one river to another and to colonize estuaries and coastal lagoons.

On the other hand, the record of the Trypanites ichnofacies provide conclusive evidence that subacuatic hard grounds existed and suggests a fast uplift of the marine bottom, changing sedimentological facies from outer continental shelf to coastal and subaquatic fan delta facies. This event marks the sedimentary filling of the Térraba basin, and 
suggests a relatively fast tectonic uplift during late Upper Miocene and the early Lower Pliocene.

Finally, a late Hemphillian NALMA age is assumed for this new fossil find and corresponds with the youngest stratigraphic rank for the Gavialosuchus americanus (Sellards, 1915).

\section{ACKNOWLEDGMENTS}

To Enrique Laurent (San Vito, Coto Brus) to whom we dedicate this work, because of his dedication to the preservation of the palaeontological patrimony of this country. This investigation has been possible thanks to the contributions of the OTS, Las Cruces Station; ESCO group, San José, and private donors. We would also like to thank an anonymous reviewer for valuable comments and suggestions on the original manuscript and Galen Randall, student of the University of Arizona, for the help in revision and correction of this manuscript in English.

\section{REFERENCES}

AUFFENBERG, W.A., 1954: Additional specimens of Gavialosuchus americanus (Sellards) from a new locality in Florida.Quart. J. Fla. Acad. Sci. 17:185-209.

ANTUNES, M.T., 1961: Tomistoma lusitanica, Crocodilien du Miocène du Portugal.- Rev. Fac. Cienc. Lisboa, 2 ser. 9(2):5-88.

BROCHU, C.A., 1997: Synonymy, redundancy, and the name of the crocodile stem-group.J. Vert. Paleontol. 17(2): 448-449.

BROCHU, C.A., 1999: Phylogenetics, Taxonomy, and Historical Biography of Alligatoroidea. Memory 6. - J. Vert. Paleontol. 19 (supplement to number 2): 9-100.

BROCHU, C.A, 2001: Crocodylian Snouts in Space and Time: Phylogenetic Approaches Toward Adaptive Radiation.- Amer. Zool., 41: 564-585.
BROCHU, C., 2006: Osteology and phylogenetic significante of Eosuchus minor (Maersh, 1870) new combination, a longirostrine crocodylian from late Paleocene of North America.- J. Paleontol. 80(1): 162-186.

BROCHU, C. \& RINCÓN, A.D., 2004. A gavialoid crocodylian from the Lower Miocene of Venezuela.- Sp. Pap.Palaeontol. 71: 61-78.

BUFFETAUT, E., 1982: Systématique, Origene et Évolution des Gavialidae Sud-Américains.In: BUFFETAUT, E., (Ed.): Phylogénie et Paléobiogeographie: Livre Jubilaire en l'honneur de Robert Hoffstetter.- Geobios, Sp. Mem. 6: 127-140.

CLARK, W.B., SHATTUCKG, B. \& DALL, W.H., 1904: The Miocene deposits of Maryland.- Maryland Geol.1 Surv. Systematic Report, 1-509.

COPE, E.D., 1869: The Fossil Reptiles of New Jersey.- The Amer. Naturalist, 3(2): 84-91.

COPE, E.D., 1875: Synopsis of the Vertebrata of the Miocene of Cumberland County, New Jersey.- Proc. Amer. Philos. Soc. 14 (94): 361-364.

ESTES, R. \& BÁEZ, A., 1985: Herpetofaunas of North and South America during the Late Cretaceous and Cenozoic: Evidence for Interchange?.- In: STHELI, F.G. \& S.D. WEBB (Eds.): The Great American Interchange.- Plenum Press. Chapter 6: 140-197. New York.

KÄLIN, J.A., 1955: Crocodilia.- In PIVETEAU, J. (ed.): Traité de paleontologie, 5: 695784. Masson, Paris.

LAURITO, C.A., VALERIO, A.L., GÓMEZ, L.D., MEAD, J.I., PÉREZ, E.A. \& PÉREZ, L.G., 2005: A Trionichidae (Reptilia: Testudines, Cryptodira) from the Pliocene of Costa Rica, Southern Central America.Rev. Geol. Amér. Central, 32: 7-11. 
LANGSTON, W. \& GASPARINI, Z., 1997: Crocodilians, Gryposuchus, and the South American Gavials.- In: KAY, R.F., MADDEN, R.H., CIFELLI, R.L. \& FLYNN,J.J.(Eds.): VertebratePaleontology in the Neotropics - The Miocene Fauna of La Venta.- Smithsonian Institution Press. Chapter 8: 113-154.Washington.

MEAD, J.I., LAURITO, C., VALERIO, A.L., SWIFT, S. \& CUBERO, R., 2004. The Late Pliocene-Early Pleistocene fauna of El Indio, SW Costa Rica.- J. Vert. Palaeontol. 24, 92A.

MEAD, J.I., CUBERO, R., VALERIO, A.L., SWIFT, S.L., LAURITO, C.A. \& GÓMEZ, L.D., 2006: Plio-Pleistocene Crocodylus (Crocodylia) from southwestern Costa Rica.- Studies on Neotropical Fauna and Environment, 41 (1): 1 - 7.

MEYLAN, P.A., AUFFENBERG W.A. \& HULBERT, R.C., 2001: Chapter 7: Reptilia 2 Lizards, Snakes and Crocodilians. In HULBERT, R.C. (Ed.): The Fossil Vertebrates of Florida.- Univ. Press of Florida, Gainesville, 137-151.

MEYLAN, P.A., AUFFENBERG W.A. \& HULBERT, R.C., 2006: The Fossil Vertebrates of Florida. Other additions and corrections. http://www.flmnh.ufl.edu/vertpaleo/book.htm\#addcor [July, 2006].

MYRICK,A.C.,2001:Thecachampsaantiqua(Leidy, 1852) (Crocodylidae, Thoracosaurinae) from fossil marine deposits at Lee Creek Mine, Aurora, North Carolina, USA. - In RAY, C. \& BOHASKA, D. (Eds.): Geology and Paleontology of the Lee Creek Mine, North Carolina III.- Smithsonian Contributions to Paleobiology, 90: 219-225.
MOOK, C.C., 1921: Skull characters and affinities of the extinct Florida gavial Gavialosuchus americana (Sellards).Bull. Am. Mus. Nat. Hist. 44: 33 - 41.

MOOK, C.C., 1924: Further notes on the skull characters of Gavialosuchus americana (Sellards).- Amer. Mus. Novitates; 155:1-2.

MOOK, C.C., 1959: A new Pleistocene Crocodilian from Guatemala.- Amer. Mus. Novitates, 1975:1-6.

MORGAN, G.S., 1986: The so-called Giant Miocene Dolphin Megalodelphis magnidens Kellog (Mammalia: Cetacea) is actually a Crocodile (Reptilia: Crocodilia).J. Palaeontol. 60 (2): 411-417.

RAPP, W.F., 1944: Check list of the fossil reptiles of New Jersey. J. Palaeontol. 18 (3): 285-288.

SANCHEZ-VILLAGRA, M.R., BURNHAM, R.J., CAMPBELL, D.C., FELDMAN, R.M., GAFFNEY, E.S., KAY, R.F., LOZSÁN, R., PURDY, R. \& THEWISSEN, J.G., 2000: A Near-shore Marine Fauna and Flora from the Early Neogene of Northwestern Venezuela.- J. Palaeontol. 74 (5): 957-968.

SELLARDS, E. H., 1915: A New Gavial from the Late Tertiary of Florida.- Amer. Journ. Sci., (4) XL: 135-138.

SELLARDS, E.H., 1916: A New Tortoise and a Supplementary Note on the Gavial, Tomistoma americana.- Amer. J. Sci. (4) XLII: 235-240.

SILL, W.D., 1968: The Zoogeography of the Crocodillia.- Copeia, 1968 (1):76-88. 
TOULA,F.\&KAIL,J.A., 1885.UbereinenKrokodilSchadel aus den Tertiarablagerungen von Eggenbergin Niederosterrich.-Denkschriften der Akademie der Wissenschaften, Vienna, v. 50: 299-356.

VÉLES-JUARBE, J., BROCHU, C.A. \& SANTOS, H., 2007: A gharial from the
Oligocene of Puerto Rico: transoceanic dispersal in the history of a non-marine reptile.- Proc. Royal Soc. Biol.1 Sci. 274 (1615): 1245-1254

YOUNG, C.C., 1964: New fossils crocodiles from China.- Vertebrata Palasiatica 8 (2): 199-208. 